\title{
津波による港湾内の流況と地形変化に関する実験およびその数值計算
}

\section{Hydraulic Experiment on Flow and Topography Change in Harbor due to Tsunami and Its Numerical Simulation}

\author{
藤井直樹 $^{1} \cdot$ 池野正明 ${ }^{2} \cdot$ 榊山 勉 $^{3}$ ・松山昌史 ${ }^{4} \cdot$ 高尾 誠 $^{5} \cdot$ 向原 健 $^{6}$ \\ Naoki FUJII, Masaaki IKENO, Tsutomu SAKAKIYAMA \\ Masafumi MATSUYAMA, Makoto Takao and Takeshi MUKOHARA
}

\begin{abstract}
Numerical model of topography change is important to examine collapse of the harbor facilities by sand transport due to tsunami. Problems for evaluation of sand transport due to tsunami with topography change model are in precision of the numerical model and topography change data. Therefore, we installed the harbor in large-scaled wave tank and carried out experiment about tsunami flow and topography change to get those detailed data. For results provided by experimental test, we applied the topography change model of Ikeno et al. (2009a) and evaluated it about the reproduction characteristics. As a result, it was confirmed that reproduction of an experiment improved by using new pickup rate formula proposed by Ikeno et al. (2009a).
\end{abstract}

\section{1.はじめに}

2004年インド洋大津波では, 大量の侵食と堆積が報告 された。このような土砂移動の発生を定量的に予測する ことは，港湾施設の倒壊等に対する安全性や対策の必要 性を検討する上でも重要である．津波による地形変化の 予測については，藤井ら（1998）や高橋ら（1999）によ る1960年チリ津波時の気仙沼湾の地形変化事例の検討, 西畑ら（2005）によるインド洋大津波時のキリンダ漁港 の地形変化事例の検討がある。しかしながら, 海底地形 変化予測モデルを用いて定量的に評価するためには, 既 提案モデルの予測精度だけでなく, 地形変化事例の測量 精度も含めて、検討上の課題が残されている.

そこで, 本研究では港湾内における海底地形変化の予 測モデルの構築を目指し, 港湾を設置した大型平面水槽 を用いた津波による流況と地形変化に関する実験を実施 し，予測モデルの検証データを取得するとともに，港湾 における流況・地形変化特性の把握を行う。次に, 平面 実験により得られた結果を対象として，池野ら（2009a） の地形変化モデルを適用し, その再現性について検討 する.

\section{2. 平面水槽実験}

\section{（1）実験の概要}

港湾における津波による地形変化を把握することを目

\begin{tabular}{lllll}
\hline 1 & 正会員 & 博 (工) & 東電設計株式会社 社会基盤推進部 \\
2 & 正会 & 工博 & 電力中央研究所 環境科学研究所 \\
3 & 正会 & 博 (工) & 電力中央研究所 地球工学研究所 \\
4 & 正会貝 & 博(工) & 電力中央研究所 地球工学研究所 \\
5 & 正会員 & 工修 & 東京電力株式会社 原子力設備管理部 \\
6 & 正会貝 & 工修 & 鹿島建設株式会社 技術研究所
\end{tabular}

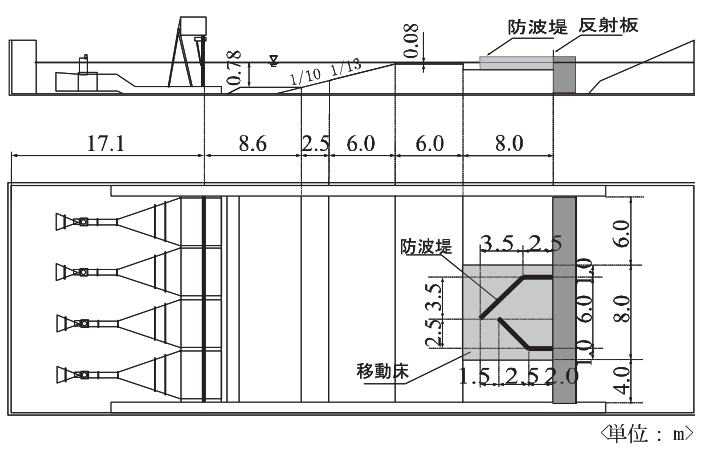

図-1 平面水槽の概略図

的に, 図-1に示す大型平面水槽（長さ $58 \mathrm{~m}$, 幅 $20 \mathrm{~m}$, 深 さ $1.6 \mathrm{~m}$ ）内に港湾を模擬した防波堤（厚さ $0.15 \mathrm{~m}$ ）と護 岸を設置し，水位と流速の平面分布を計測する固定床実 験と砂移動による海底地形変化量を計測する移動床実験 の両者について, 縮尺 $1 / 100$ の港湾模型を想定した水理 実験を実施した。防波堤と護岸の高さは，津波が越流し ない高さとした。ただし，移動床実験に用いた砂は中央 粒径 $0.08 \mathrm{~mm}$ である.

固定床実験では，港内外に波高計・流速計を設置し， 港内を $0.5 \mathrm{~m}$ 間隔, 港口部を $0.25 \mathrm{~m}$ 間隔でデータを計測し た。移動床実験では, 海底砂の厚さを $0.15 \mathrm{~m}$ とし, 港湾 模型を含む $8 \mathrm{~m} \times 8 \mathrm{~m}$ を移動床範囲とした．海底地形の計 測は, 造波前の初期地形と造波後の海底地形を沿岸方向 に $0.1 \mathrm{~m}$ の測線間隔, 港口部付近のみ $0.05 \mathrm{~m}$ の測線間隔で レーザー変位計を移動させて測深した.

実験で造波した津波条件は, 周期 60 秒の半周期分, 片 振幅 $6 \mathrm{~cm}$ である。 


\section{（2）移動床実験状況}

写真-1に示すように，津波が港口に入射した際に防波 堤から渦の発生が見られた。また，主防波堤および副防 波堤の角部から砂が巻き上がることが確認された．発生 した渦は港内で次第に大きくなり，巻き上げられた浮遊 砂の多くは, 渦の中心に集まり, 水位低下時に浮遊砂は 港外へ流出された。この時, 主防波堤側では防波堤に沿 った流れ，副防波堤側では角部の渦によって砂の卷き上 がりが生じていた。

図-2に2 回実施した移動床実験による地形変化量を示 す. 2 回の実験による地形変化パターンに差がないこと から実験の再現性は良いことがわかる，港口部では速い 流れによって侵食し，港内に運ばれた砂は写真-1に見ら れた港内の渦中心部に相当する箇所で堆積している. ま た．港口部から港外においても侵食域が見られるが，こ れは引き波時の港口部の高流速によるものであり，侵食 された砂は港外へ浮遊して運ばれていた。
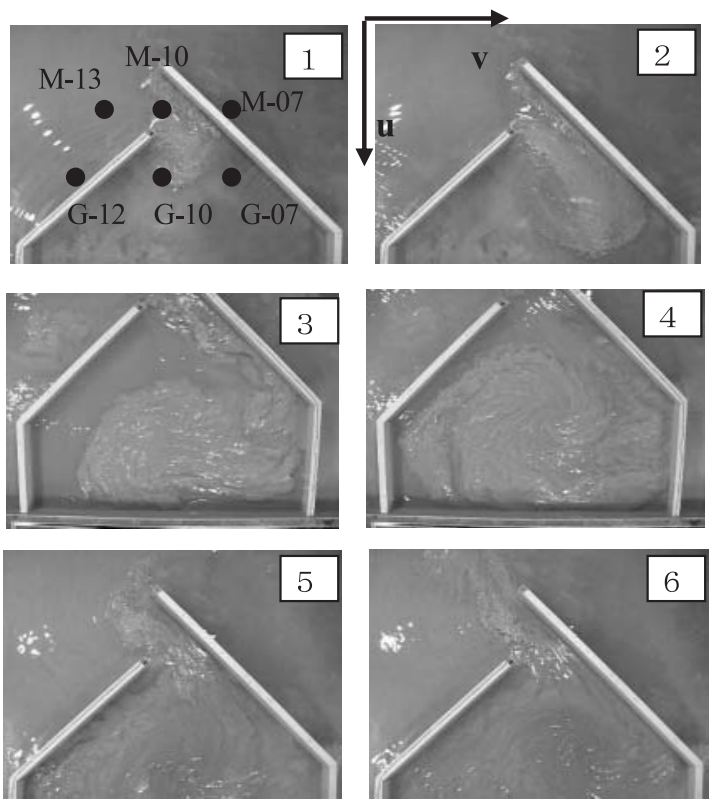

写真-1＼cjkstart移動床実験のスナップショット

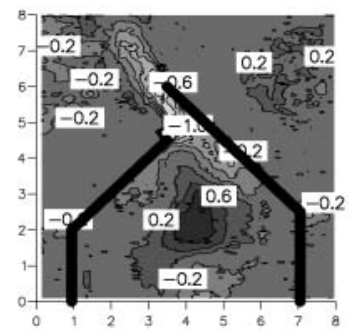

(a) 1 回目

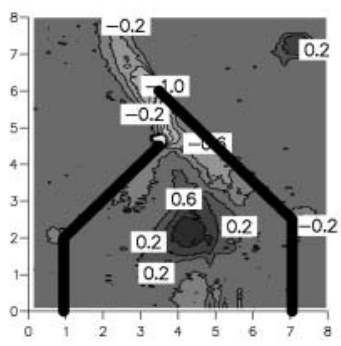

(b) 2 回目
図-2 実験による地形変化（単位： $\mathrm{cm},+$ 堆積 一侵食)

\section{3. 地形変化モデルの概要}

津波による地形変化の計算は高橋ら（1999）と同様に， 非線形長波方程式による平面 2 次元の津波伝播計算から 水位・流速を求め，それを外力とした底質の移動につい て掃流砂の連続式と浮遊砂の移流拡散方程式を解くこと で実施した。

以下に，後の実験再現計算で用いた高橋ら（1999）と 池野ら（2009a）の2つの地形変化モデルと地形変化に係 わる計算式を示す。

（1）高橋ら（1999）の地形変化モデル

高橋ら（1999）の地形変化モデルにおける掃流砂量算 定式と掃流層・浮遊層間の交換砂量 $w_{\mathrm{ex}}$ を以下に示す.

$$
\begin{aligned}
& \frac{q_{B}}{\sqrt{s g d^{3}}}=21 \psi^{3 / 2} \\
& \frac{w_{e x}}{\sqrt{s g d}}=0.012 \psi^{2}-\frac{w \bar{C}}{\sqrt{s g d}} \\
& \psi=\frac{u_{*}^{2}}{s g d}
\end{aligned}
$$

ここに, $q_{B}$ : 単位幅当たりの掃流砂量, $\psi$ : シールズ 数, $s$ : 砂の水中比重, $g$ : 重力加速度, $d$ : 砂の粒径, $w$ : 沈降速度, $\bar{C}$ : 平均浮遊砂濃度である. 式 (2) の右 辺第 1 項は砂の巻上量, 第 2 項は砂の沈降量として提案 されたものである. 式（1）および式（2）の右辺第1項 の $\psi$ に関する係数は， $0.2 \mathrm{~mm}$ の砂実験に基づき提案され ている.

（2）池野ら（2009a）の地形変化モデル

池野ら（2009a）は，トラップ実験結果との比較から 掃流砂量の算定式として，河川流を対象に適用実績の高 い次の芦田・道上（1972）の式が有効であることを示 した.

$$
\frac{q_{B}}{\sqrt{s g d^{3}}}=17 \psi^{3 / 2}\left(1-\psi_{c} / \psi\right)\left\{1-\left(\psi_{c} / \psi\right)^{1 / 2}\right\}
$$

また, 浮遊砂の巻上量 $P$ の算定式としては, 砂粒径効 果を考慮した次式の無次元巻上量算定式が提案された。

$$
\frac{P}{\sqrt{s g d}}=a\left(v^{2} / s g d^{3}\right)^{0.2}\left\{(w / \sqrt{s g d})^{0.8}\left(\psi-\psi_{c}\right)\right\}^{2} \cdots(5)
$$

ここに, $\psi_{c}$ : 限界シールズ数, $v$ : 動粘性係数である. 池野ら (2009b) は, 係数 $a$ を既往の実験結果から $0.1 〜 0$. 2 の範囲と推定しており, 本研究では実験の再現計算結 果を踏まえてその範囲内で設定する. 式（5）と高橋式 （2）の右辺第 2 項を比べると巻上量式中のシールズ数項 以外の部分が砂粒径により変化することがわかる（池野 ら, 2009a).

ここで，砂の粒径を $0.08 \mathrm{~mm}, a=0.15$ とした場合，巻上 量 $P$ は $0.056\left(\psi-\psi_{c}\right)^{2}$ となる。 また, 砂の粒径を $0.2 \mathrm{~mm}, a$ $=0.15$ とした場合, 巻上量 $P$ は $0.015\left(\psi_{-} \psi_{c}\right)^{2}$ となり, 高橋 

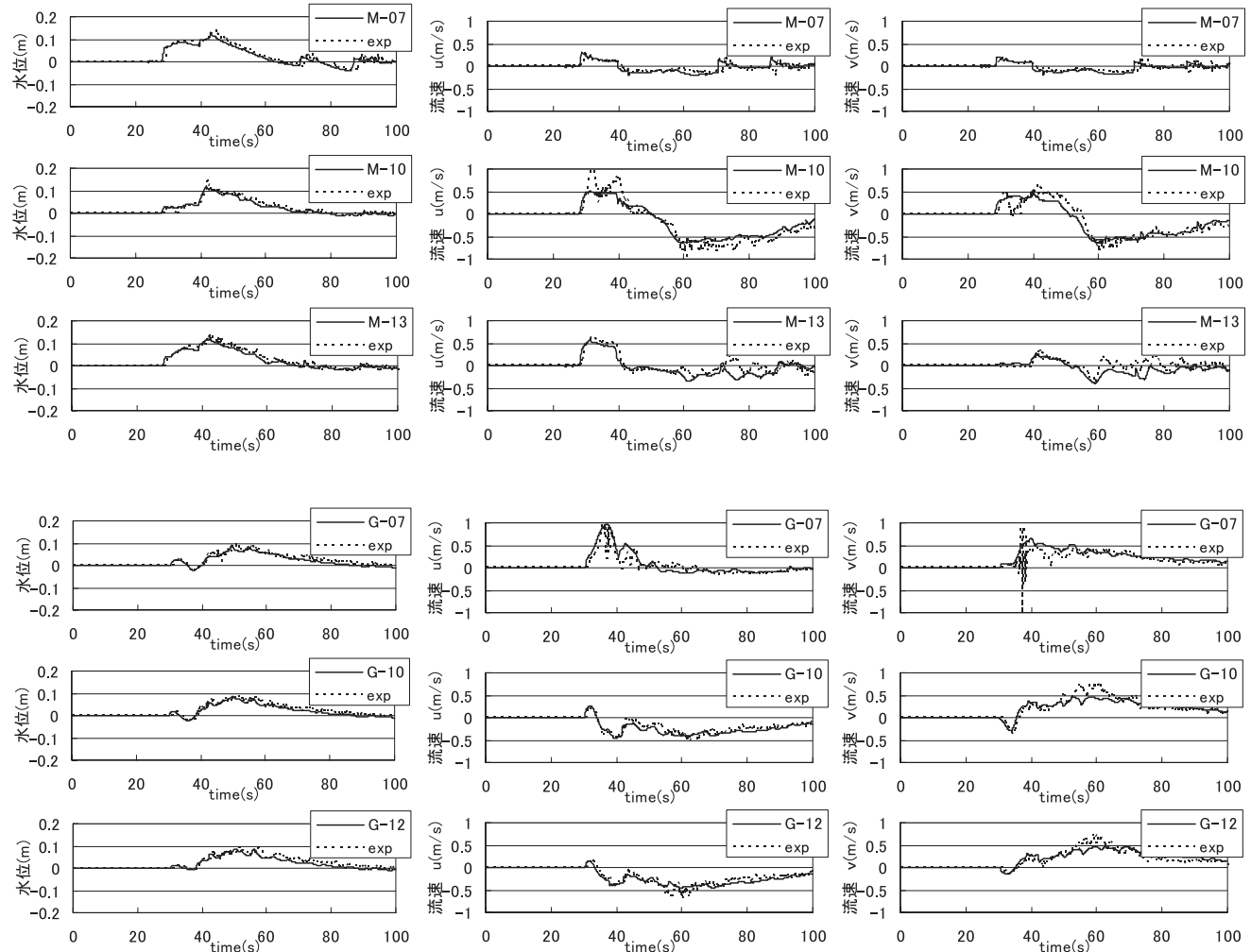

図-3 水位・流速波形の計算結果（実線）と実験結果（点線）の比較

ら（1999）の地形変化モデルにおける式（2）の右辺第1 項の係数 0.012 と同程度となっている.

\section{(3) 掃流砂と浮遊砂の計算}

地形変化の計算には、次式に示す掃流砂量の連続式と 掃流層・浮遊層間の交換砂量式を用いる.

$$
\begin{aligned}
& \frac{\partial z_{B}}{\partial t}+\frac{1}{1-\lambda}\left(\frac{\partial q_{B x}}{\partial x}+\frac{\partial q_{B y}}{\partial y}-P+w C_{b}\right)=0 \\
& \frac{\partial \bar{C} D}{\partial t}+\frac{\partial \bar{C} M}{\partial x}+\frac{\partial \bar{C} N}{\partial y}-P+w C_{b} \\
& =\frac{\partial}{\partial x}\left(K_{h} \frac{\partial \bar{C} D}{\partial x}\right)+\frac{\partial}{\partial y}\left(K_{h} \frac{\partial \bar{C} D}{\partial y}\right)
\end{aligned}
$$

ここに, $Z_{B}$ : 基準面からの底面高さ， $\lambda$ : 底面砂の空 隙率, $q_{B x}, q_{B y}$ : 掃流砂量の $x, y$ 方向成分, $C_{b}$ : 底面濃 度, $M, N$ : 津波計算から求められる $x, y$ 方向成分の線 流量, $K_{h}$ : 水平渦粘性係数, $D$ : 全水深である.

式（6）, 式（7）の $w C_{b}$ は沈降量を示しているが，沈降 量に係わる濃度としては，式（2）の右辺第2項の平均濃 度と底面濃度を用いる方法がある。沈降に関して平均濃 度を用いる方法では，浮遊砂層からの沈降量が過小評価 されると考えられる。また，池野ら（2009a）は浮遊砂 濃度の鉛直分布が指数分布で適用可能であることを実験 によって確認している。 そこで本研究では, 浮遊砂濃度
の鉛直分布を指数分布と仮定して底面濃度を用いること とした．以下に用いた底面濃度について述べる。

浮遊砂濃度の鉛直分布 $C^{\prime}(z)$ は, 鉛直拡散係数 $k_{z}$ を用いて,

$$
C^{\prime}(z)=C_{b} \exp \left(-\frac{w}{k_{z}} z\right)
$$

と仮定する。また，鉛直拡散係数 $k_{z}$ は，藤井ら（1998） にならい未定定数 $c_{k}(=0.2)$ を用いて以下のように仮定する.

$$
k_{z}=\kappa u_{*}(h+\eta) \times c_{k}
$$

したがって，底面濃度は次式で求められる。

$$
C_{b}=\frac{w(h+\eta)}{\left[1-\exp \left\{-w(h+\eta) / k_{z}\right\}\right]} \bar{C}
$$

ここに, $\kappa$ ：カルマン定数 $(=0.4), u^{*}$ : 摩擦速度, $\eta$ : 水位である。

\section{4. 実験の再現計算結果}

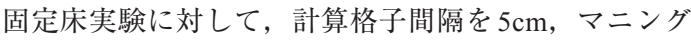
の粗度係数を $0.012 \mathrm{~s} / \mathrm{m}^{1 / 3}$ ，拡散係数を $0.0001 \mathrm{~m}^{2} / \mathrm{s}$ とした津 波計算を実施した。実験と計算の水位・流速時間波形の 比較を図-3に示す。比較点は，写真-1に示した 6 点であ る. 水位の時間波形は，進行波と 40 秒以降の港湾内の反 射波も含めて実験結果を良く再現できている．流速の場 合，港口部 M-10の実験結果は急激に流速が大きくなる 
が, 計算結果はその半分程度であった。港口部を除けば 2 方向とも計算結果は, 実駼結果の時間変化を十分に再 現できている.

流速べクトルの比較を図-4に示す，計算の流速べクト ルは実験結果と概ね一致しているが，30秒の港口部付近 の計算結果が実験結果より小さい. それ以外については, 押し波時に扔いて防波堤先端部で渦が発生し, その結果, 縮流されて流れが加速される状況，港内で時計回りの大 きな循環流が形成される状況, 引き波時に港内から港外 へ高流速が発生する状況，その後港内に渦が僅かに残っ ている状況が両結果とも確認され, 計算結果は実験結果 を概ね再現できている。

図-5に高橋ら（1999）と池野ら（2009a）の地形変化モ デルによる地形変化量の計算結果と唫験結果の比較を示 す．池野ら（2009a）の地形変化モデルでは，沈降項の 浮遊砂濃度として平均濃度と底面濃度を用い, 再現を試 みた。また, 池野ら（2009a）の地形変化モデルでは, 巻上量算定式（5）の係数 $a$ を変化させて計算した. 図に は, 実験結果と比較して再現性が良かった 0.15 の場合の 結果を示している．図から，押し波時の流況に対応した 港口部から港内にかけての侵食，同様に引き波時に港口 部から港外にかけての侵食, 港内中央部の渦の中心付近 への堆積傾向は, 計算結果と実駼結果で一致しているこ

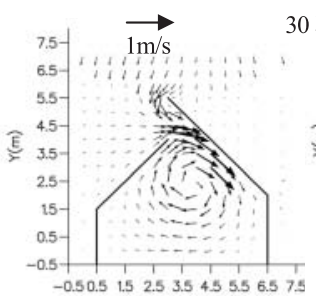

$x(m)$

$x(m)$

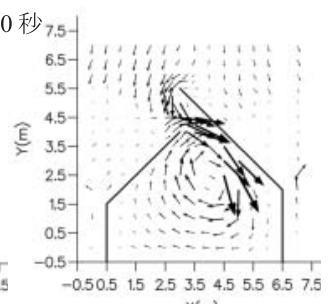

$X(m)$

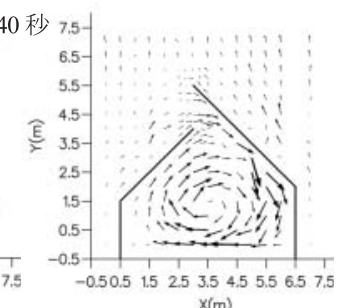

$x(m)$

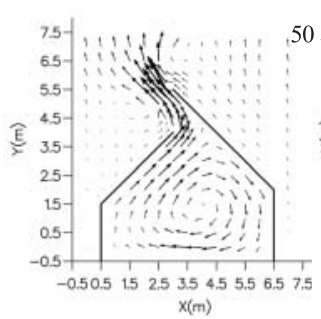

(a) 計算結果

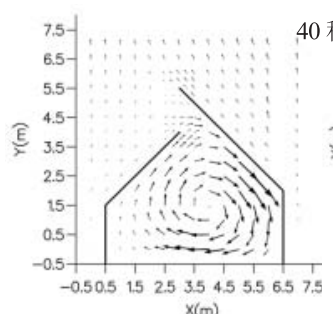

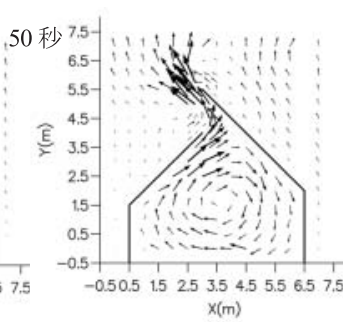

(b) 実験結果 図-4＼cjkstart流速ベクトルの比較
とがわかる. しかし, 高橋ら（1999）の地形変化モデル による計算では港口部の侵食が過大であるため浮遊砂の 上限濃度を $5 \%$ としてそれ以上巻き上がりが発生しない ようにしているにもかかわらず侵食量が多く，そのため 堆積範囲が広くなった。一方, 池野ら（2009a）の地形 変化モデルによる計算では, 巻上量算定式 (7) の係数 $a$ を 0.15 とすることによって侵食が実験と同程度となっ た。ただし，沈降項に扔いて平均濃度を用いた場合，堆 積し難くなり, 実験に比べて港内中心付近の堆積量が過 小評価であった。そこで, 沈降項に底面濃度を用いるこ とにより, 堆積高さ $0.2 \mathrm{~cm}$ のコンターは実験と同範囲に 改善された。しかしながら, 港内中心の堆積高さは過小 評価となっており，これに関しては今後の課題である.

図-6に池野ら（2009a）の地形変化モデルによる地形 変化量と砂の濃度分布の時間変化の計算結果を示す，砂 の濃度分布は図-4の流速べクトルと良く対応した分布形 状である。また，濃度は $2 \%$ 以下であった。港内におけ る堆積は，40～50秒の引き波が始まる時間以降において 生じていることがわかる. 渦中心の濃度は小さくなって いるが，写真-1では渦中心に濁りが見られる。計算にお いて港内中央部の堆積值が小さい原因としては, 榊山 （2008）が指摘する洞中心に向かう2次流を今回の計算で 考虑していないことが考えられる.

図-7は領域に分けた侵食量と堆積量を計算と実験との 比で比較したものである. 高橋ら（1999）の地形変化モ デルは，侵食量と堆積量とも全体的に過大である. 池野 ら（2009a）の地形変化モデルの沈降項に底面濃度を用 いた場合の計算では，巻上量算定式（5）の係数 $a$ を 0.1 , $0.15,0.2$ と変化させた。 $a=0.1$ の結果は侵食量と堆積量

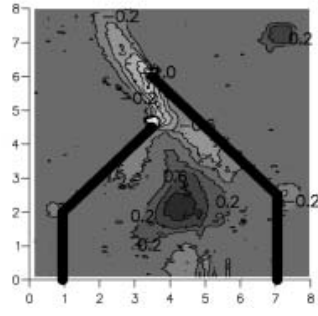

(a) 実験結果

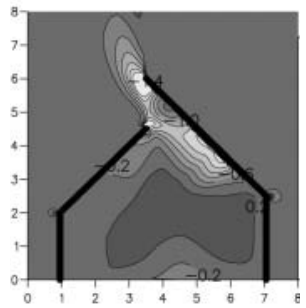

(c) 池野ら (2009) $(a=0.15)$ 沈降項 : 底面濃度

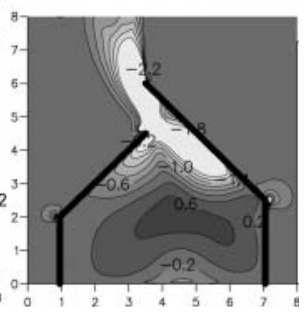

(b) 高橋ら(1998)

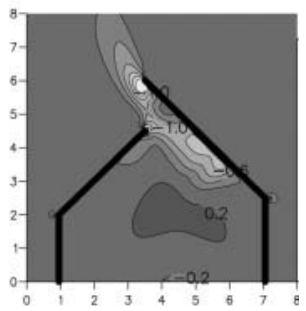

(d) 池野ら (2009) $(a=0.15)$ 沈降項 : 平均濃度
図-5 地形変化量の比較 (単位： $\mathrm{cm}$, +堆積 - 侵食) 

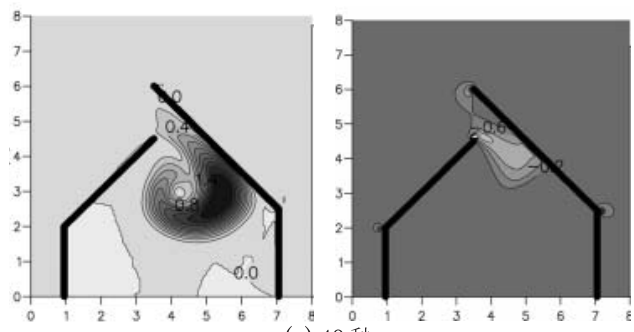

(a) 40 秒

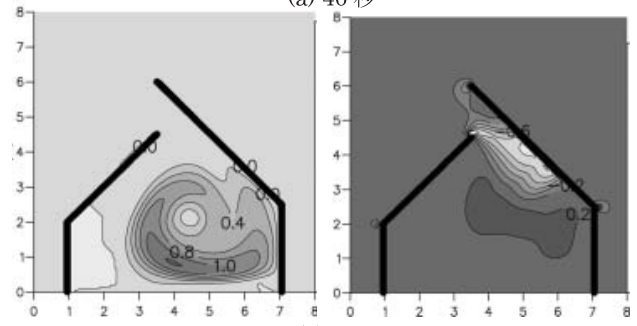

(b) 50 秒
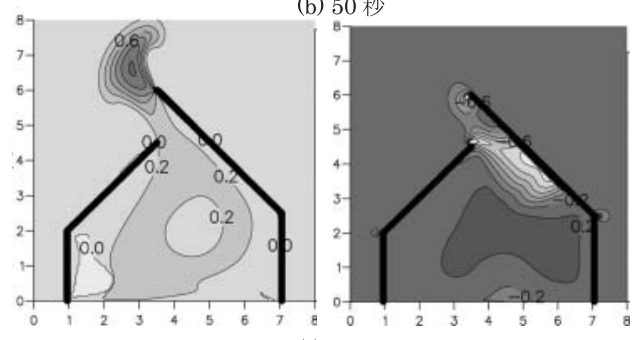

(c) 60 秒

十堆積 一侵食

濃度分布 $(\%)$

地形変化量 $(\mathrm{cm})$

図-6 計算による砂の濃度分布と地形変化量

が全体的に小さく,$a=0.2$ の結果は全体的に大きめであ る. $a=0.15$ の結果は, 実験の再現性が最も良好と判断さ れる.

\section{5. おわりに}

本研究では，津波による地形変化の予測モデルの構築 を目指して，平面水槽内に防波堤模型を設置した水位と 流速の平面分布を計測する固定床実験と砂移動による海 底地形変化量を計測する移動床実験を実施し，予測モデ ルに必要な検証デー夕を取得するとともに，その再現計 算を実施した。以下に得られた結果を示す。

・防波堤先端部から発生した渦は港内中央部を中心とし た循環流となること，港口部では速い流れによって侵 食されて渦中心部で堆積することが把握された.

- 固定床実験の再現計算から, 実験結果と港内流況が概 ね一致することを確認した。

・地形変化モデルを用いて実験の再現計算を実施した結 果，池野ら（2009a）のモデルは実験に比べて港内中 央部の堆積高さは過小であるものの, 港口部で大きく 侵食し, 渦中心部に堆積域が生じる傾向が再現できた. このときの浮遊砂濃度は, 最大で $2 \%$ 程度であった。

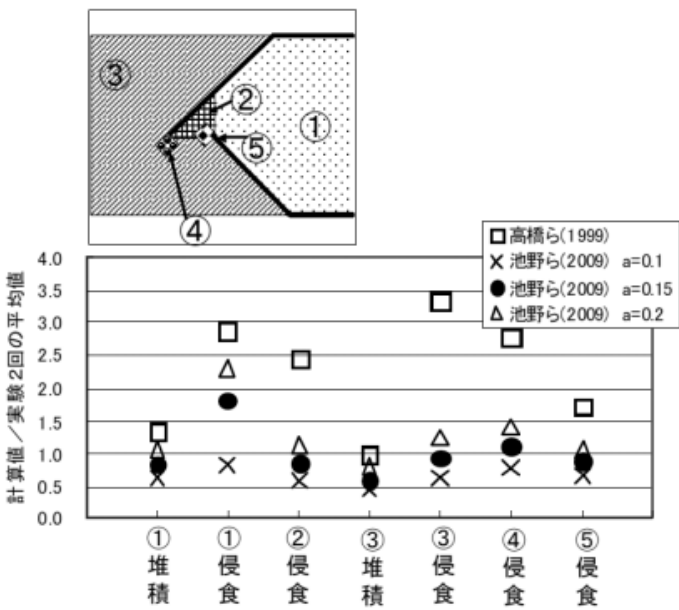

図-7 領域別地形変化量の比較

・高橋ら（1999）のモデルによる計算結果は，実験に比 べて侵食量と堆積量とも過大に評価された。これは, 巻上量式が砂粒径 $0.2 \mathrm{~mm}$ の実験に基づいているためで あり，異なる砂粒径に適用する場合は，池野ら（2009a） の砂粒径効果を考慮した巻上量式によって再現が向上 することを確認した。

今後は港湾中央部の堆積高さの課題について検討し, 地形変化モデルの精度向上を図る必要がある.

謝辞：本研究は, 電力 11 社による電力共通研究として実 施した成果であることを付記するとともに，(社）土木学 会原子力土木委員会津波評価部会（主査 首藤伸夫日本 大学教授）の委員や先生方に，研究成果をご審議頂き, 有益なご助言を賜りました。ここに記して謝意を表す。

\section{参 考 文 献}

芦田和男 - 道上正規 (1972）：移動床流れの抵抗と掃流砂量に 関する基礎的研究，土木学会論文報告集，第206号，pp.59-69. 池野正明・吉井 匠・松山昌史・藤井直樹（2009a）：津波に上 る砂移動量実験と浮遊砂卷上量式の提案, 電力中央研究所 研究報告 V08064, 43p.

池野正明・吉井 匠・松山昌史・藤井直樹（2009b）：津波実験 に基づく浮遊砂卷上量の算定と卷上量式の提案，海岸工学 論文集, 第 56 巻（投稿中).

榊山 勉・松山昌史・木原直人（2008）：津波による港湾内の 海底地形変化に及ほす流速場の影響，海岸工学論文集，第 55 巻, pp. $256-260$

高橋智幸・首藤伸夫 - 今村文彦・浅井大輔（1999）：掃流砂層・ 浮遊砂層間の交換砂量を考慮した津波移動床モデルの開発, 海岸工学論文集, 第46巻, pp.606-610.

西畑 剛・田島芳満・森屋陽一・関本恒浩（2005）：津波に上 る地形変化の検証 -2004年スマトラ沖地震津波 スリラン カ・キリンダ港-，海岸工学論文集，第 52巻，pp.1386-1390。 藤井直樹 - 大森正則 - 高尾 誠 - 金山 進 - 大谷英夫 (1998)： 津波による海底地形変化に関する研究, 海岸工学論文集, 第45巻, pp.376-380. 